\section{Exogenous IBA and Inoculation with Agrobacterium rubi Stimulate Adventitious Root Formation on Hardwood Stem Cuttings of Two Rose Genotypes}

Sezai Ercisli, ${ }^{1}$ Ahmet Esitken, ${ }^{1}$ and Fikrettin Sahin ${ }^{2}$

Faculty of Agriculture, Ataturk University 25240 Erzurum, Turkey

Additional index words. Dogrose, rooting, auxin, bacteria

Abstract. During Fall and Winter 1999-2000 and 2000-2001, a study was conducted to evaluate the effects of exogenous IBA application $(0,2000$, or $4000 \mathrm{ppm})$ and inoculation with Agrobacterium rubi (strains A1, A16, or A18) alone or in combination with each bacterial strain on rooting of hardwood stem cuttings of two rose selections (ERS 14, Rosa canina, and ERS 15, Rosa dumalis). Treatments of hardwood stem cuttings with IBA, bacteria alone and in combination with IBA were found to promote rooting. The highest rooting percentage was obtained among ERS 14 cuttings when treated with 4000 ppm IBA plus A. rubi A16. However, optimal rooting of ERS 15 was obtained when treated with 2000 ppm IBA plus $A$. rubi A18. Better rooting was observed in thornless ERS 15 genotype than in thorny ERS 14 genotype in both years. Chemical name used: $1 \mathrm{H}$,indole3-butyric acid (IBA).

Recently there has been increasing interest in growing less well-known fruit species such as rose hip that have both economic and ornamental value. Most rose species are widely distributed in the Middle and Eastern Anatolia regions of Turkey (Nillson, 1997). These species are often found along roadsides, in hedgerows or at the edge of woods under a range of climatic and soil conditions (Ercisli, 1996).

Most rose seedlings, except those belonging to Rosa canina and Rosa rubiginosa, obtained from the same parent have displayed varied horticultural characteristics due to a high degree of heterogeneity present within rose species (Werlemark et al., 1995). Vegetative propagation would allow selection of rose hip cultivars with good cultural adaptation (Ercisli and Guleryuz, 1999). Propagation of genotypes cultivated for rose hip by layering or tissue culture is limited by poor regeneration and low survival rate (Esitken, 1998). It is believed that propagation of these genotypes by cuttings might be easier and more economical (Uggla, 1991).

There are many physiological and environmental factors that influence adventitious root formation, with exogenous treatments on cuttings being particularly important (Couvillon, 1988). Rooting of temperate zone fruit species is often difficult and people have attempted to stimulate rooting by applying growth regulators, carbohydrates, and various chemical substances (Doud and Carlson, 1972; Ercisli and Read, 2001). It is well known that auxins have an important role in rooting of hardwood

Received for publication 5 Nov. 2002. Accepted for publication 6 June 2003

Dept. of Horticulture.

${ }^{2}$ Dept. of Plant Protection.

cuttings among many temperate species including Rosa spp. (Bhujbal and Kale, 1975; Sim and Lawes, 1981)

Recent studies confirm that bacteria in several genera (Agrobacterium, Bacillus, Streptomyces, Pseudomonas, and Alcaligenes) induce root formation in stem cuttings (Bassil et al., 1991; Hatta et al., 1996; Rinallo et al., 1999). These bacteria stimulate the production of endogenous indole-3-acetic acid (IAA) (Goto, 1990), which has worked synergistically with exogenous $1 \mathrm{H}$,indole-3-butyric acid (IBA) applications to improve rhizogenesis in hazelnut (Bassil et al., 1991) and walnut (Falasca et al., 2000). The objective of our study was to determine the effect of IBA concentration $(0$, 2000, and 4000 ppm), inoculation with Agrobacterium rubi, and date of cutting collection on adventitious root formation on hardwood cuttings of two rose hip genotypes.

\section{Material and Methods}

Hardwood stem cuttings of two important rose hip genotypes (Rosa canina line ERS 14 and thornless Rosa dumalis genotype ERS 15) were collected at the beginning of October and at the end of February. Cuttings were subjected to 1 of 12 treatments. For IBA treatments, the basal portion of cuttings were dipped for 5 min in a 2000 or 4000 ppm aqueous solution of IBA dissolved in $50 \%$ ethanol and allowed to air dry (for $30 \mathrm{~min}$ ). Bacterial treatments were performed by dipping the cuttings into Agrobacterium rubi (strains A1, A16, or A18) bacterial suspensions prepared in sterile water at a concentration of $10^{9} \mathrm{cfu} / \mathrm{mL}$. IBA+ bacteria combined treatments were achieved by dipping IBA treated cuttings into the bacterial suspension. Cuttings in the control group were dipped in $50 \%$ ethanol. Following treatment, cuttings were placed to a depth of $10 \mathrm{~cm}$ in trays filled with perlite and incubated under mist (15 s/6 min) in a greenhouse maintained at $21 \pm 2{ }^{\circ} \mathrm{C}$. The experiment was completely randomized design with three replications. Each replication contained 20 cuttings spaced $50 \mathrm{~mm}$ apart. Data were transformed (arcsine) prior to statistical analysis and subjected to analysis of variance (ANOVA). Means were separated by Duncan's multiple range test and orthogonal contrasts.

\section{Results and Discussion}

Cuttings of both rose genotypes treated with IBA and Agrobacterium rubi rooted better than the control cuttings in both experimental years (Table 1). However, the two genotypes responded differently to the imposed treatments. Rooting percentage was similar between sampling dates for both genotypes. Therefore data for the sampling dates were pooled.

For genotype ERS-15, optimal rooting was achieved when hardwood cuttings were treated with 2000 ppm IBA plus inoculation with $A$ rubi strains A16 or A18 (Table 1). Rooting of this genotype was reduced when treated solely with IBA or inoculated with $A$. rubi without treatment with IBA. In addition, inoculation with $A$. rubi strain A1 was less effective than A16 or A18. Rooting of control cuttings was $\approx 12 \%$ that of the optimum treatment.

Overall, rooting of ERS-14 hardwood cuttings was lower than those of ERS-15. In addition, the optimal treatments differed for the two genotypes (Table 1). While optimum rooting of ERS-14 hardwood cuttings was obtained when treated with IBA and $A$. rubi, a higher IBA concentration was required and the synergistic effect of combining IBA and A. rubi was less evident than for ERS-15. The optimum IBA concentration for rooting of ERS-14 was 4000 ppm, twice that required for ERS-15. Addition of A. rubi also improved rooting over IBA alone. Rooting percentage was greater when cuttings were treated with strain A16 compared to A1. However, rooting percentages of cuttings treated with A16 and A18 were similar.

Our results are similar to those of Ivanicka and Pastyrik (1978) and Ercisli and Guleryuz, (1999), indicating that hardwood stem cuttings of rose hip genotypes rooted best when treated with 2000 to 5000 ppm IBA. It is evident that cuttings of different fruit species require different optimum concentrations of IBA for best rooting as illustrated by our results with these genotypes.

It is known that inoculation with Agrobacterium can induce adventitious rooting in recalcitrant woody genotypes. Bassil et al., (1991), showed that rooting percentage of hazelnut stem cuttings was improved when inoculated with A grobacterium. Esitken et al., (2003), tested three bacteria strains for rooting of wild sour cherry cuttings and found that Agrobacterium rubi A16 was the best. Our results also demonstrate that inoculation with A. rubi improves rooting of rose genotypes with specificity for $A$. rubi strains being evident among Rosa canina and Rosa dumalis. 
Table 1. Effects of IBA and Agrobacterium rubi on the rooting (\%) of hardwood stem cuttings of ERS-14 and ERS-15 rose hip genotypes in 2000 and 2001.

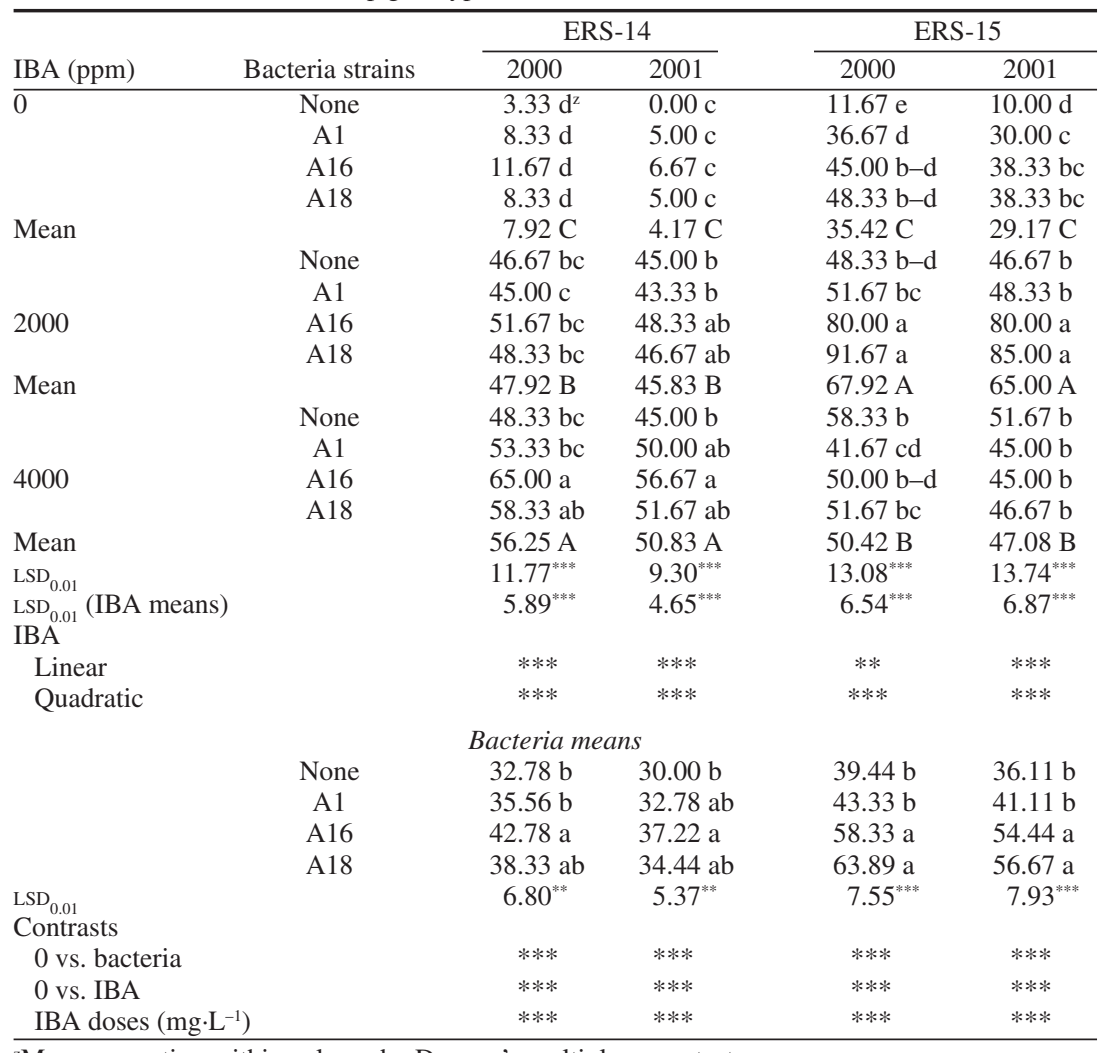

${ }^{\mathrm{z}}$ Mean separation within column by Duncan's multiple range test.

${ }^{* * * * * *} P \leq 0.01, P \leq 0.001$, respectively.

Adventitious rooting might be induced in recalcitrant woody genotypes by inoculation with Agrobacterium strains, and, in most cases, might also require exogenous auxin. Falasca et al. (2000) showed that rooting on the bacteria inoculated walnut cuttings was enhanced by exogenous IBA treatments. Our results were in general agreement with previously reported data (Bassil et al., 1991; Benavides, 1998; Esitken et al., 2003), showing that IBA-bacteria combined treatments had more capacity for enhancing rooting of cuttings than IBA or bacteria alone treatments.

In order to interpret these results, the major question that could be asked was the mechanism of IBA action and bacterial strains, which had additive effects on rooting of plant cuttings. Auxins are stimulating initiation of adventitious roots because of its effect on cell division. Therefore, exogenous application of an auxin group like IBA may induce root formation on the cuttings used for plant propagation.
In other studies, root enhancement by Agrobacterium sp. was thought to be correlated with endogenous indole-3-acetic acid (IAA) production. Since the Agrobacterium rubi strains used in our study were not examined for IAA production, further studies are underway to investigate the exact role of Agrobacterium rubi on rhizogenesis in these rose hip genotypes.

\section{Literature Cited}

Bassil, N.V, W.M. Proebsting, L.W. Moore, and D.A. Lightfoot. 1991. Propagation of hazelnut stem cuttings using Agrobacterium rhizogenes. HortScience 26:1058-1060.

Benavides, M.P. and S. Radice. 1998. Root induction in Simmondsia chiensis (Link) Schneid. using Agrobacterium rhizogenes. Biocell 22:109-114

Bhujbal, B.G. and P.N. Kale. 1975. Effect of some growth regulators on rooting of cuttings of different rootstocks of rose (Rosa spp.). Hort. Abst. 45:521.

Couvillon, G.A. 1988. Rooting responses to different treatments. Acta Hort. 227:187-196.

Doud, S.L. and R.F. Carlson. 1972. Propagation methods of fruit tree cultivars from hardwood cuttings. Hort. Abst. 43:4178.

Ercisli, S. 1996. The selection and propagation of rose hips naturally grown in Gumushane region of Turkey. PhD. thesis. Ataturk Univ, Erzurum.

Ercisli, S. and M. Guleryuz. 1999. A study of the propagation of the hardwood cuttings of some rose hips. Tr. J. Agr. For. 23 (Suppl. 2):305-310.

Ercisli, S. and P.E. Read 2001. Propagation of hazelnut by softwood and semi-hardwood cuttings under Nebraska conditions. Acta Hort. 556:275-280.

Esitken, A. 1998. A study on the micro propagation of Rosa canina and Rosa dumalis. PhD. thesis. Ataturk Univ, Erzurum.

Esitken, A, S. Ercisli, . Sevik, and F. Sahin. 2003. Effect of Indole-3-Butyric Acid and different strains of Agrobacterium rubi on adventive root formation from softwood and semi-hardwood wild sour cherry cuttings. Tr. J. Agr. For. 27:37-42.

Falasca, G, M. Reverberi, P. Lauri, E. Caboni, A. De Stradis, and M.M. Altamura. 2000. How Agrobacterium rhizogenes triggers de novo root formation in a recalcitrant woody plant: An integrated histological; ultrastructural and molecular analysis. New Phytol. 145:77-93.

Goto, M. 1990. Fundamentals of bacterial plant pathology. Academic Press, New York.

Hatta, M, C.A. Beyl, S. Garton, and A.M. Diner. 1996. Induction of roots on jujube softwood cuttings using Agrobacterium rhizogenus. J. Hort. Sci. 71:881-886.

Ivanicka, S. and L. Pastyrik. 1978. The utilization of 3 -indol-butyric acid in rooting hardwood cuttings of tree fruits. Acta Hort. 80: 83-85.

Nillson, Ö. 1997. Flora of Turkey and the East Aegean Islands, p. 106-128. vol. 4. P.H. Davis (ed.).Edinburgh Univ. Press.

Rinallo, C, L. Mittempergher, G. Frugis, and D. Mariotti. 1999. Clonal propagation in the genus Ulmus: Improvement of rooting ability by Agrobacterium rhizogenus T-DNA genes. J. Hort. Sci. Biotechnol. 74:502-506.

Sim, B.L. and G.S. Lawes. 1981. Propagation of kiwifruit from stem cuttings. Gartenbauwissenschaft 46:65-68.

Uggla, M. 1991. Development of rose hip cultivars and growing techniques for establishment of plantations. Sveriges Lantbruksuniversitet 52-55.

Werlemark, G, U.Carlson-Nilsson, M. Uggla, and H. Nybom. 1995. Effects of temperature treatments on seedling emergence in Dogroses, Rosa Sect Caninae (L). Section B, Soil and Plant Sci. Acta Agr. Scand. 45:278-282. 